\title{
A SZUBJEKTÍV TÉRÉRZÉKELÉSSEL KAPCSOLA- TOS VIZSGÁLATOK ELMÉLETI HÁTTERE ÉS ALKALMAZÁSI TERÜLETEI
}

\author{
(The Theoretical Background and Field of Application of \\ Subjective Spatial Perception Researches)
}

\section{GARDA VERONIKA}

\begin{abstract}
Kulcsszavak:
szubjektivitás kognitiv térkép mentális térkép sztereotípia

A tanulmány a szubjektiv térérzékeléshez kapcsolódó fogalmak (kognitiv és mentális térképek, térképezés) tisztázása után bemutatja a tudati kép kialakulását befolyásoló fó tényezōket. A témához kapcsolódó szakirodalmi áttekintés alapján a Szerzö vázolja a mentális térkép (mint kutatási módszer) alkalmazásának lehetöségeit. A vizsgált területegységek méretét alapul véve ismerteti a módszer alkalmazási területeit települési, regionális és országos (kontinentális) szintü kutatásokban.
\end{abstract}

\section{Bevezetés}

A geográfia és a pszichológia határterületén, főként e két tudományág ismeretanyagának, nézeteinek, eszköztárának összekapcsolódásából született - a földrajz „klasszikus” irányzataihoz képest még mindig újnak mondható - behaviorista geográfia. Az 1960-as években, elsőként az Amerikai Egyesült Államokban megjelenő iskola képviselői a hagyományos térfelfogással szemben a társadalom által érzékelt teret helyezték a középpontba ( $L y n c h$ 1960). Míg az elöbbi esetben egy adott, hoszszabb-rövidebb ideig állandó környezetröl van szó, az utóbbi dinamikus, változatos, személyenként eltérö - és ami a leglényegesebb - „tudati” képződményt jelent. A vizsgálatok alapjául szolgáló módszert, a „mentális térképezést”, számos szakterület kutatói beemelték eszköztárukba, így a geográfia mellett a szociológia, a kulturális antropológia, a városrendezés egyes területein is alkalmazzák.

\section{Fogalmi áttekintés a kognitív térképektöl a mentális térképekig}

A mentális térképezés módszerének és felhasználási területeinek bemutatása előtt mindenképp tisztázandók a témához szorosan kapcsolódó fogalmak, hiszen ezek nemcsak a különbözö tudományágak szakirodalmában, hanem sokszor a geográfián belül is eltérö tartalommal bírnak. Mivel a behaviorista geográfia egyik alappillére az a felfogás, hogy az emberek viselkedését és cselekedeteit a tér objektív szerkezete 
helyett annak szubjektív érzékelése határozza meg, így a külvilágnak a tapasztalatok alapján történő egyéni leképezése a „kognitivv térképezés" elnevezést kapta (Cséfalvay 1990). A folyamat végtermékeként felfogható ,kognitiv térkép" a területekről alkotott ismeretek mellett az egyén véleményével - és gyakran sztereotípiákkal - füszerezett képet jelent a külvilágról. A térkép elnevezésnek annyiban megfelel, hogy jellemzően kartográfiai elemekre épül - helyek, irányok, távolságok, koordináták -, de ezekhez a már említett, egyéntől függö (pozitív és negatív) tartalmak kapcsolódnak. A térképi elemek szerepe a tájékozódásban meghatározó, míg a hozzá kapcsolt további tudati tartalmak az élet számos területén befolyásolják az egyén viselkedését (munkavállalás, turizmus, migráció stb.).

A tudatunkban élö információk felszinnre hozása csupán módszertani probléma, melynek megoldására napjainkig a legkülönfélébb felmérés-típusok születtek. Az eredmények felhasználásával valódi térképeket készíthetünk, melyek tükrözik a vizsgált személy(ek) látásmódját, véleményét, illetve egy társadalmi csoportnak a környezetéról alkotott tudati képét. A módszert általában „mentális térképezésnek”, a segítségével elkészült térképet pedig "mentális térképnek" nevezik (Cséfalvay 1990). Ennek megfelelóen ez utóbbi a kognitív térképeken alapul, de annál lényegesen kevesebb tartalommal bír, mindössze szemléltetése annak, amit a vizsgálat során egy adott csoport kognitív térképeiról megtudtunk.

Bár a ,kognitiv" illetve a „mentális térkép" fogalmát több szerzö nem különíti el, hanem szinonimaként használja, jelen tanulmányban azok a már ismertetett, különböző jelentést hordozzák. Mindezt azért tartjuk szükségesnek, mert két teljesen különböző, ellentétes irányú folyamatról van szó: az első esetben a külvilágtól az egyén felé irányuló, befogadó, ismeretet raktározó müveletröl; a második esetben azoknak az „elöhívásáról” és térképi megjelenítéséről, mindig az adott vizsgálat céljának megfelelően. A folyamat talán a fényképezéshez hasonlítható a leginkább, ahol az exponálás és az elóhívás eltérő múveletet jelent.

\section{A tudati kép kialakulását befolyásoló tényezók}

A mentális térképezés legkorábbi, a geográfusok által is gyakran idézett alkalmazása Kevin Lynch nevéhez füzödik, aki az Egyesült Államokban vizsgálta a nagyvárosok szerkezete és a kognitív térképek közötti kapcsolatot. Kutatása arra próbált fényt deríteni, hogy a település struktúrája befolyásolja-e azok "olvashatóságát", vagyis mennyire könnyủ az adott várost a tudatunkban modellezni. Az elkészült térképek alapján arra a következtetésre jutott, hogy a városok szerkezete, utcahálózata, tagoltsága, egyedisége az, ami hatással van a rajzok minóségére (Lynch 1960; 1965).

Későbbi vizsgálatok mutattak rá arra, hogy az egyének kognitív térképeit sokkal inkább befolyásolja saját társadalmi helyzetük, mint a város olvashatósága. A személyes tapasztalatnak ugyanis sokkal nagyobb szerepe van a pontos rajz elkészítésében, mint a város szerkezetének. Ezt Peter Orleans gyakran említett vizsgálata 
A szubjektív térérzékeléssel kapcsolatos vizsgálatok elméleti háttere és alkalmazási területei. Tér és Társadalom 23. évf. 2009/1. 43-53. p.

TÉT XXIII. évf. 2009 1 A szubjektiv térérzékeléssel ...

bizonyítja, hiszen Los Angelesről a különböző társadalmi osztályokhoz tartozó személyek eltérő részletességủ rajzokat készítettek (Orleans 1973).

Az egyén személyisége és a mentális térképek közötti összefüggéseket is vizsgálták már a témával foglalkozó szakemberek. Az aktivitáshoz kapcsolódó tipizálás már Peter Gould munkájában is megjelent, aki ebböl a szempontból két csoportra osztotta a társadalmat. Az egyik a felfedező, kutató embertípus (,space searchers”), a másik az, aki megelégszik szükebb környezetének megismerésével (,space sitters"). Ebböl adódóan a környezet leképezése is pontosabb az előbbi, aktív életet élö személyeknél, mint „otthonülő” társaiknál (Gould 1975; Walmsley-Jenkins 1991).

Az eddigi kutatások alapján elmondható, hogy az egyén személyisége, társadalmi helyzete, életkora, foglalkozása stb. egyaránt hatással van a külvilágról alkotott képre. A kognitív térképek közös jellemzője, hogy dinamikus „,képződmény”: napról napra változik, hiszen környezetünk információinak befogadása, majd feldolgozása során, fokozatosan alakul ki. Bár tartalmuk egyénenkẻnt különböző, az elóhívott mentális térképek - fơként az egy társadalmi csoporthoz tartozó személyek esetében - hasonlóságot is mutatnak. Ebből adódóan a módszer mind a külvilágról alkotott kép változásának nyomon követésére, mind egy adott csoport pillanatnyi ismeretanyagának, vélekedésének feltérképezésére használható.

\section{A mentális térképezés módszerei, alkalmazási területei}

Az egyén saját, a térről alkotott szubjektív képének előhívása és feldolgozása többféle módszerrel történhet. Az első, legegyszerübb eljárás Kevin Lynch nevéhez füződik, aki amerikai nagyvárosokat elemzett ,vázlatrajzos módszerrel” (Lynch 1960). Ennek lényege, hogy a felmérésben résztvevők egy üres papírlapra rajzolják a vizsgált terület térképét. A „városkép" felidézése természetesen emlékezetböl, segédeszköz igénybevétele nélkül történik. Mivel a rajzkészségból adódó különbségek torzíthatják az eredményeket, kiegészitö kérdésekkel érdemes a felidézést segíteni. Így az egyes területekhez kapcsolódó többletinformációk is könnyebben felszínre kerülhetnek.

Lynch a térképvázlatokon szereplő elemeket öt csoportba sorolta („Lynch elements"); ezeket a későbbiek során a hazai kutatók is átvették (Cséfalvay 1990; Letenyei 2005), de az elnevezések az egyes szerzőknél a fordításból adódóan különbözőek:

- paths (utak, úthálózat, útvonalak)

- edges (törés-, határvonalak)

- nodes (csomópontok)

- districts (területek, övezetek, a mentális terek neve)

- landmarks (iránypontok, tájékozódási pontok).

Az egyes elemek megléte a térképeken kapcsolatban van a megismerési folyamat egyes szakaszaival is. Kutatások irányultak a tanulási folyamat vizsgálatára is, melyek 
valószínűsítik, hogy elsőként a főbb tájékozódási pontok, majd az ezeket összekötő útvonalak kerülnek fel a kognitív térképekre, és csak ezután tudatosulnak az egyes területek elnevezései (Golledge 1978; Walmsley-Jenkins 1991).

A mentális térképek készítésénél lehetőség van arra is, hogy ne teljesen üres papírlapot kapjanak a felmérésben résztvevők. Az adott terület főbb tájékozódási pontjait, határvonalait is bejelölhetjük vaktérképszerủen - ha ez a kutatás fỏ célját nem befolyásolja.

Egy másik, gyakran alkalmazott eljárás, amikor megadott objektumokat, területegységeket kell valamilyen elv szerint rendezni. Ebben az esetben nem tényleges rajzolásról, hanem az egyén véleményének megfelelö sorrendiség megállapításáról van szó. Peter Gould és Rodney White a különböző egyetemi városok diákjainak eltérő értékelését mutatja be az Egyesült Államok mentális térképein (Gould-White 1974). A térképek ebben az esetben föleg sztereotípiákról, egyes területekhez kötődő elképzelésekről, tapasztalatokról adhatnak új információkat, hiszen így felszínre kerülnek az emberek tudatában élö ,jó és rossz helyek", melyek alapvetően befolyásolják a mindennapi életet (közlekedés, lakóhely kiválasztása, munkavállalás, turizmus).

Napjainkban a mentális térképek segítségével végzett elemzések reneszánszukat élik, a benne rejlő lehetóségeket a környezetpszichológia mellett a szociológia, a turizmus és a településkutatás szakemberei is felfedezték. Hazánkban a kilencvenes évektől kezdve jelennek meg a témához kapcsolódó kutatások eredményei, melyek közül jó néhány kapcsolódik valamilyen módon a geográfiához. Ez nem is csoda, hiszen a kognitív térképek alapvetỏen az általunk látott világ átalakított képei, így mindenképpen térbeliséget hordoznak.

A mentális térképezés (mint módszer) megvalósítása - a kérdőívezéshez, interjúzáshoz hasonlóan - az egyes elemzésekben hasonlóságot mutat, mégis, a kutatók céljai szerint, számtalan módon alkalmazható. Módszertanáról hazánkban - többek között - Letenyei László írt, akinek „,mentálistérkép-szerkesztő ábécéje” nagy segitséget jelenthet a hasonló munkákkal foglalkozóknak a felmérések megtervezése, a lekérdezések és kiértékelés során (Letenyei 2005). A kutatás menetét természetesen befolyásolja a felmérésben résztvevők életkora, társadalmi helyzete, lakóhelye, de ennél lényegesebb, hogy alapvetően meghatározó tényező a vizsgált terület mérete. A következőkben bemutatjuk a mentális térképek felhasználásának, gyakorlatban való alkalmazásának főbb lehetőségeit. Bár hazánkban eddig a kutatók viszonylag szük köre vonta be eszköztárába a módszert, mégis szinte mindannyian eltérỏ céllal alkalmazták. Mivel a vizsgált területi egységek mérete/szintje meghatározó az adott felmérés részleteinek kidolgozásánál, így a mentális térképeket felhasználó kutatásokat is ez alapján lehet leginkább kategorizálni. 


\section{Települési, település környéki vizsgálatok}

A települési szintü vizsgálatok talán leggyakoribb alkalmazási területei a mentális térképeknek. A kutatások célja lehet többek között:

- az adott község vagy város kapesolathálójának elemzése;

- a településnek a helyi lakosok szemszögébỏl való bemutatása;

- a helyi identitás vizsgálata;

- a ,pozitív” és ,negatív” területek elkülönítése;

- várostervezési, városrész-rekonstrukciós feladatok megoldása;

- a település imázsa, a turizmus tárgykỏrébe tartozó elemzések;

- a települések tudati leképeződésének vizsgálata.

A kapcsolatháló-elemzésre, a helyi társadalom kapcsolatrendszerének bemutatására leginkább szociológusok munkái között találhatunk példákat (Borsos-CsiteLetenyei 1999). Az egyes településrészek kỏzötti kapcsolatok felderítése nem csupán elméleti síkon hasznosítható: a helyi kỏzlekedés megtervezése, gazdaságossá tétele céljából is alkalmazható, a forgalomszámlálásból származó adatok ismerete mellett. Nem mindegy ugyanis, hogy a lakosoknak kellene kihasználni a meglévő vonalakon közlekedő helyi autóbuszjáratokat, vagy a hálózat átalakításával alkalmazkodnak a fogyasztók igényéhez.

A mentális terek elnevezésének és a hozzájuk köthető tudati tartalomnak, szubjektív véleménynek a vizsgálata sem csupán a helyi identitás szempontjából fontos. Az egyes városnegyedek átalakulását, a település határán belüli lakóhely-változtatásokat vagy a szuburbanizációt vizsgálva is használták, használják a mentális térképezést. A településrészekhez kötődő „pozitív” vagy „negatív” kép alapvetően befolyásolhatja a településen belüli folyamatokat, akár az ingatlanok értékének alakulását is (Letenyei 2001). Az eladó vagy kiadó ingatlanok hirdetéseiben is megfigyelhető, hogy szívesen használják a hirdetők a ,jobb nevü” mentális terek elnevezéseit - jobb esetben a „közeli”, „melletti” stb. kiegészítéssel. Így lesz Pécs esetében sok ingatlanból „,belvárosi”, „Tettye kỏzeli”, „egyetemvárosi”, „mecsekoldali”. Az egyes területek további leértékelődését, a gettósodást is elörevetítheti a helyi lakosok véleménye; ugyanakkor kiderülhet, hogy a legpreferáltabb belvárosi negyed, vagy akảr a városszéli lakótelep milyen szerepet játszik a különböző társadalmi csoportok életében (Pásztor 2004; Mester 2005). Ennek megfelelően a várostervezési, városrészrekultivációs feladatok megoldásánál szintén érdemes a mentális térképekhez nyúlni.

Ủj lehetőség a mentális térképek alkalmazására az archaikus település-típusok vizsgálata is, hiszen a legegyszerübben a vázlatrajzos, kötetlen felidézésủ módszerrel mutatható ki, hogy a helyi lakosság tudatában mennyire vannak jelen a hagyományos településszerkezet elemei (1. ábra). Kiváló mintaterület erre Székelyföld, hiszen egykori tízesei ${ }^{1}$ meghatározóak a települések mai szerkezetében is (Ambrus 2008). 


\section{1. ÁBRA}

Ahogyan egy csíkmindszenti látja a faluját

(The Way how a Man of Csikmindszent Perceives his Village)

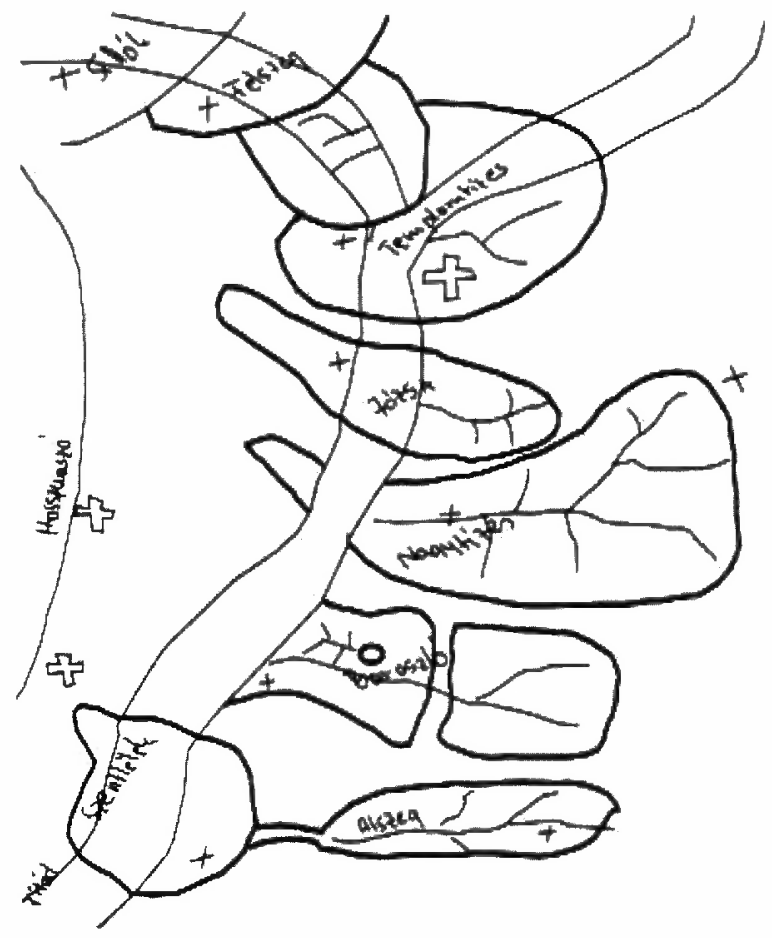

Forrás: Ambrus (2008).

A turizmus kutatásában is további lehetőségeket rejt a primer vizsgálatok e típusa: az adott település imázsa, a sztereotípiák és a valóság összevetése mind olyan kérdés, melynek megválaszolásában a helyi lakosság, valamint a turisták által „tárolt" városkép elöhívása is segítségünkre lehet (Cséfalvay-Fischer 1990).

Nyilvánvaló, hogy a települések kognitiv térképe fokozatosan, hosszú idő alatt alakul ki, illetve mindvégig megörzi dinamikus jellegét. A külvilág modellezésének egyes lépéseiről azonban még igencsak hiányosak az ismereteink. Mely objektumok rögzülnek elsőként egy számunkra ismeretlen település egészéből? Meghatározó-e ebből a szempontból az adott objektum kinézete (műemlékek, látnivalók), helyzete, esetleg a funkció a leginkább domináns (pályaudvar, vásárcsarnok)? Milyen összefüggések fedezhetök fel az életkor és a kognitív térképek között? Napjainkban külföldi egyetemi hallgatók körében folytatnak kutatásokat, mivel ők azok, akik egy települést kénytelenek néhány hét (hónap) alatt minél jobban megismerni, hogy ott tájékozódni tudjanak. 
A szubjektív térérzékeléssel kapcsolatos vizsgálatok elméleti háttere és alkalmazási területei. Tér és Társadalom 23. évf. 2009/1. 43-53. p.

TÉT XXIII. évf. 2009 घ

A szubjektiv térérzékeléssel ...

\section{Régiós vizsgálatok, a határok kérdése}

Ha a határok és a mentális terek kérdése települési vagy kistérségi szinten vizsgálható és vizsgálandó, akkor ugyanez régiós szinten sem hanyagolható el. Főleg napjainkban, amikor a „régiók világát” éljük hazai és európai szinten, regionális együttmüködésről, eurorégiókról, regionális identitásról beszélünk. Bár a vita a hazai régiók határairól a szakemberek körében már lecsengett, és a határok megmerevedni látszanak, mégis érdemes a régiók mentális képével és tudati határaival is foglalkozni. Különösen akkor, ha egyetértünk azzal, hogy a tartós együttlét, a hagyományok, a kialakult közös értékrend tartja össze az adott régióban élőket (Tóth 2004). Ennek megfelelően fóként a megyékből kialakított régiók „hivatalos”, valós határai állnak messze - az esetek legnagyobb részében - ugyanezen területeknek az emberek fejében élö, évtizedekre visszanyúló, hagyományos határaitól. A településeken belüli mentális terekhez (városrészek, települések elemi egységei) hasonlóan a régió-kép és a regionális identitás is vizsgálható a mentális térképezés módszerével. Kimutatható, hogy melyek egy adott régió fó ismertetőjegyei a társadalom nézőpontjából, melyek a legismertebb területei, milyen eltéréseket mutat a határok meghúzása attól függően, hogy a válaszadók (rajzolók) mely társadalmi csoportba tartoznak, hol élnek, milyen korúak. Vizsgálható, hogy egyáltalán létezik-e régiókép, ha igen, mennyire egységes a régión belül; de legalább ennyire érdekes, hogy milyennek vélik a határain kívül élők ugyanazt a területet.

Mindez különösen fontos napjainkban, a turizmus-fejlesztés oldaláról nézve, hiszen a szakemberek évek óta igyekeznek az egyes terỉleteknek egységes, megfogható, külföldiek által is azonosítható ,arcot” adni, turisztikai ,imázst” teremteni.

A régiós vizsgálatra példaként saját felmérésünk eredményének egyik mentális térképét mutatjuk be (2. ábra), mely kaposvári középiskolások körében készült 2006-ban a Dél-Dunántúlról. A települések említésének arányát a településeket jelző körök mérete mutatja, míg az egyéb földrajzi nevek ismertségét a különbözó betútípusok jelzik. Látható, hogy a diákok „Dél-dunántúli régiója” sokkal inkább magában foglalja Zala megyét, mint Tolna megyét; ,fehér foltjai” ugyanakkor nem csupán a hiányos ismeretekről, hanem a közlekedési problémákról is árulkodhatnak (Gál 2006).

A határok kérdése természetesen nem csak a belső, régióhatárokat érinti, hiszen gyakori terepe a mentális térképezésnek az országhatár egy-egy szakaszának két oldala is. A lakosság hajlama az egyuittmủködésre vagy az elzárkózásra alapvetően meghatározhatja egy határ menti együttmủködés sikerét vagy kudarcát, hiába történnek meg a megfelelö politikai és adminisztratív lépések (Hardi 1999; HardiNárai 2001). Ezek a vizsgálatok különösen Kelet-Közép-Európában lennének fontosak, hiszen a rendszerváltozás, majd az Európai Unióhoz való csatlakozás feloldotta a határok merevségét, de a lakosság sztereotípiáit, ,szomszédairól” alkotott képét valószínúleg változatlanul hagyta. A kérdés csupán az, vajon mi történik ezekkel, a fejekben máig élö, merev határokkal. Azok mennyi idő után „nyílnak meg" egy ilyen soknemzetiségú területen, mint Európa? 


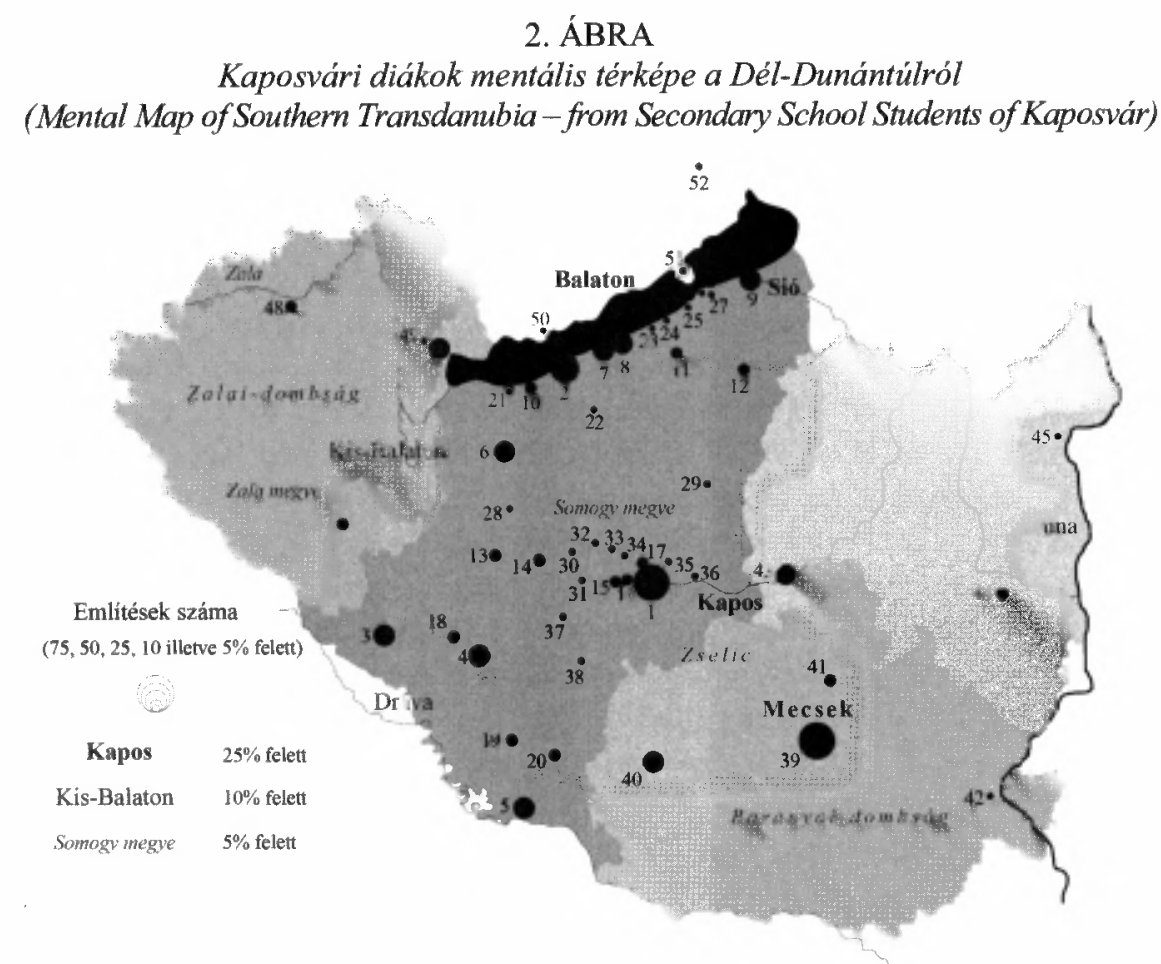

Az ábrán szereplö számok a következő településeket jelölik:

Somogy megye: 1) Kaposvár 2) Fonyód 3) Csurgó 4) Nagyatád 5) Barcs 6) Marcali 7) Balatonboglár 8) Balatonlelle 9) Siófok 10) Balatonfenyves 11) Kötcse 12) Tab 13) Böhönye 14) Nagybajom 15) Kaposmérỏ 16) Kaposújlak 17) Kaposfüred (Kaposvár) 18) Bolhás 19) Csokonyavisonta 20) Szulok 21) Balatonmáriafürdő 22) Lengyeltóti 23) Balatonszemes 24) Balatonszárszó 25) Balatonföldvár 26) Szántód 27) Zamárdi 28) Mesztegnyő 29) Igal 30) Somogysárd 31) Kiskorpád 32) Mezőcsokonya 33) Hetes 34) Juta 35) Toponár (Kaposvár) 36) Taszár 37) Csököly 38) Kadarkút Baranya megye: 39) Pécs 40) Szigetvár 41) Komló 42) Mohács Tolna megye: 43) Dombóvár 44) Szekszárd 45) Paks Zala megye: 46) Keszthely 47) Nagykanizsa 48) Zalaegerszeg 49) Hévíz Veszprém megye: 50) Badacsony 51 ) Tihany 52) Veszprém

Forrás: Mentális térképezés alapjản saját szerkesztés.

\section{Országképek}

A mentális térképek alkalmazásának harmadik területi kategóriája az országképek vizsgálata. A már említett, egyes országokról és azok lakosságáról alkotott tudati képünk nem csak a határ menti együttmüködések sikereiben vagy kudarcaiban érhetó tetten. Mivel sztereotípiáink alapvetỏen befolyásolnak minket turisztikai célú döntéseinkben, a munkavállalásnál vagy a lakóhely kiválasztásánál, ugyanez az országok közötti választásunkat is meghatározhatja. 
A szubjektív térérzékeléssel kapcsolatos vizsgálatok elméleti háttere és alkalmazási területei. Tér és Társadalom 23. évf. 2009/1. 43-53. p.

A kutatások ezen a területi szinten három csoportba oszthatók:

- egy kontinens pozitív és negatív területeinek vizsgálata;

- szomszédos országok vizsgálata;

- egy adott országról kialakult kép elemzése.

Európára vonatkozóan hazai kutatások is napvilágot láttak, melyek az országok kedveltségi rangsorát állították fel adott társadalmi csoportnál. Az eredmények alapján készült Európa térképek új oldaláról mutatják be a kontinenst: „pozitív" és „negatív” országok mozaikjaként (Bajmócy-Csíkos 1997). Nyilvánvalóvá vált, hogy az egykori vasfüggöny máig érezteti hatását, hiszen a nyugati országokról sokkal kedvezőbb a tudati kép, míg az „ismeretlen” Kelet-Európa nem igazán vonzó még nyaralás tervezésekor sem.

A szomszédos országokkal kapcsolatos vizsgálatoknál kerülnek leginkább előtérbe az egyes nemzetekhez kapcsolódó elöítéletek, a történelmi múltból eredỏ negatív érzések. Kérdés, hogy ezek a vélemények mennyire tükrözik a személyes tudást, vagy még inkább az egyéni tapasztalatot és mennyire táplálkoznak a tudatunkban élö sztereotípiákból. Vajon mennyiben változnak meg az elöítéletek a tapasztalat hatására? A különböző életkorban vagy időpontban végzett felmérések a kognitív térképek kialakulásának módját is vizsgálhatják. Az általános és középiskolások által rajzolt térképek segitségével a földrajz- és történelemtanítás hatékonysága is elemezhető, kimutatható, hogy melyek az elsődleges információforrások az adott korosztály számára (Lakotár 2007).

Természetesen a kutatás korlátozódhat egy bizonyos országra is, így a mentális térképek egyik alkalmazási területe a saját országról alkotott kép elemzése, a fejekben élő és a valós országkép összevetése, az ismert és ismeretlen területek felderitése, a kognitív térképek kialakításáért felelős tényezők vizsgálata (Kiss-Bajmócy 1996). A közvetlen és közvetett információkból egyaránt következtetni lehet a válaszadóknak a hazájukkal kapcsolatos véleményére, ugyanakkor a honismerettel kapcsolatos felmérésekhez is szolgáltathat kiegészítő, a kérdőívekhez képest sokkal inkább „térbeli” alapanyagot. Egy adott, külső országról készült mentális térkép ugyanakkor a turizmusban dolgozó szakembereknek adhat segítséget, mivel az ismert desztinációkon túl a területhez - és társadalmához - tudati szinten kapcsolódó fogalmak, ismeretanyag meglétét is igazolhatja vagy cáfolhatja. Így vizsgálható, mi befolyásolja például a magyar fiatalokat egy potenciális célállomással kapcsolatos döntésük meghozatalában (Michalkó 1998).

\section{Összegzés}

A mentális és kognitív térképek a geográfia, a térképészet, a pszichológia és a szociológia sajátos metszetét alkotják. Ezek a „belső térképek” évezredek óta segitik tájékozódásunkat, ugyanakkor környezetünknek egy általunk megélt, sztereotípiákkal, szubjektív elemekkel teli, egyedi lenyomatát jelentik. A mentális térképezés 
módszere a kilencvenes évektől kezdődően hazánkban is a legkülönfélébb elemzésekben kapott szerepet, napjainkban pedig fiatal kutatók hívják fel a figyelmet a benne rejlő újabb lehetőségekre. Tehetik (tehetjük) ezt mindazért, mivel a módszer alkalmazási területe rendkívül sokszínü, az adatok felvétele és a kapott térképek feldolgozása a vizsgálat céljának - és leginkább a vizsgált terület nagyságának megfelelöen szabadon alakítható, a kérdőíves felmérésekhez képest szabadabb, rugalmasabb adatgyüjtést tesz lehetôvé. A raszter és vektor-grafikus szoftverek térhódításával az eredmények megjelenítése is egyre egyszerübbé, látványosabbá válik, a térképek könnyen értelmezhető módon mutatják be, hogyan is látja egy adott társadalmi csoport szủkebb vagy tágabb lakóhelyét, milyen ismeretekkel, véleménnyel bír „szomszédairól” vagy a világról. Nem szabad elfelejteni azonban, hogy a kapott térkép csupán az adott felmérésben résztvevők mentális térképe, mely a külvilágról alkotott teljes kognitív térképünknek szük keresztmetszete. A mentális térképezés módszerei közül a kutatás céljának, területegységének leginkább megfelelő típus megtalálása és alkalmazása viszont segíthet abban, hogy minél közelebb jussunk a valós tudati képhez, térképhez.

\section{Jegyzet}

${ }^{1}$ Belterületi objektumokat jelölő köznévi lexéma, a székely nyelvjárásban falurészt jelent. Településtörténeti és tájföldrajzi fogalom, a székely társadalomszervezés legkisebb egysége. Árpád-kori társadalmunk tízes és százas egységekbe való rendeződésének sok változáson átment, napjainkig fennmaradt területi megjelenése (Ambrus 2008).

\section{Irodalom}

Ambrus T. (2008) A székelyfóldi falutizesek a turizmus fókuszában. Mentális térképek alkalmazása kistérségi hatókörü kutatásban. Kézirat.

Bajmócy P.-Csíkos CS. (1997) Európai országok népszerüsége egyetemi hallgatók körében. - Iskolakultúra. 6-7.71-77. o.

Borsos E.-Csite A.-Letenyei L. (szerk.) (1999) Rendszerváltozás után - Falusi sorsforduló a Kárpátmedencében. MTA PTI - SZÁMALK Kiadó, Budapest.

Cséfalvay Z. (1990) Térképek a fejünkben. Akadémiai Kiadó, Budapest.

Cséfalvay Z.-Fischer W. (1990) Cigányzene és lakáshiány - sztereotípiák és a valóság ellentéte a Budapest-képben. - Földrajzi Értesitố. 1-4. 207-220. o.

Gál V. (2006) Középiskolás vizsgálati csoportok Dél-Dunántúl képe kognitív térképeken. - Pap N. (szerk.) A Balatontól az Adriáig. Lomart Kiadó, Pécs. 201-210. o.

Gould, P.-White, R.R. (1974) Mental Maps. Penguin, Harmondsworth.

Gould, P. (1975) Acquiring spatial information. - Economic geography. 51. 87-99. o.

Golledge, R.G. (1978) Leaming about urban environments. - Timing space and spacing time. 1. 76-98. o.

Hardi T. (1999) A határ és az ember - az osztrák-magyar határ mentén élők képe a határól és a „másik oldalról”. - Nárai M.-Rechnitzer J. (szerk.) Elválaszt és összeköt-a határ. Társadalmi-gazdasági változások az osztrák-magyar határ menti térségben. MTA RKK, Pécs-Győr. 159-189. o.

Hardi T.-Nárai M. (2001) A határ és a határmentiség: A mentális kép vizsgálata négy osztrák-magyar határ menti településen. - Comitatus. 1-2.42-52. 0 .

Kiss J.-Bajmócy P. (1996) Egyetemi hallgatók mentális térképei Magyarországról. - Tér és Társadalom. 2-3. 55-68. o. 
A szubjektív térérzékeléssel kapcsolatos vizsgálatok elméleti háttere és alkalmazási területei. Tér és Társadalom 23. évf. 2009/1. 43-53. $p$.

TÉT XXIII. évf. 2009 घ

A szubjektiv térérzékeléssel ...

Lakotár K. (2007) A 14-16 éves tanulók hazánk szomszéd országairól alkotott kognitiv térképeinek tartalmi elemzése. PhD értekezés. Kézirat. Pécs.

Letenyei L. (2001) Településtervezés és mentális térképezés. - Falu Város Régió. 1. 11-15. o.

Letenyei L. (2005) Településkutatás - A települési és térségi szervezés társadalomtudományos alapozása. Ráció Kiadó, Budapest. 147-185. o.

Lynch, K. (1960) The image of the city. MIT-Press, Cambrige/Mass.

Lynch, K. (1965) Structure de la perception urbaine. - Choay, F. (ed.) L'Urbanisme-utopies et réalités. Paris. 278-289. o.

Mester T. (2005) Pécsi városlakók mentális térképei. - N. Kovács T.-Böhm G.-Mester T. (szerk.) Terek és szövegek. Ujabb perspektivák a városkutatásban. Kijárat Kiadó, Budapest. 67-83. o.

Michalkó G. (1998) Mentális térképek a turizmus kutatásában. A magyar középiskolások Olaszország képe. - Tér és Társadalom. 1-2.111-125. o.

Orleans, P. (1973) Differential cognition of urban residents: Effect of social scale on mapping. - Downs, R.M.Stea, D. (eds) Image and Environment. Aldine, Chicago. 115-130. o.

Pásztor Gy. (2004) Monostor(ok)-kép(ei), Monostor(ok)-tudat(ai). Kolozsvár egyik lakótelepének mentális térképéröl. - WEB Szociológiai folyóirat. 13, 17-24. o.

Tóth J. (2004) Kell-e nekünk régióo - Mindentudás Egyeteme. 3. kötet. Kossuth Kiadó, Budapest. 193212. 0 .

Walmsley, D.J.-Jenkins, J.M. (1991) Mental maps, locus of control, and activity: A study of business tourists in Coffs Harbour. - The Journal of Tourism Studies. 2. 36-42. 0.

\section{THE THEORETICAL BACKGROUND AND FIELD OF APPLICATION OF SUBJECTIVE SPATIAL PERCEPTION RESEARCHES}

\section{VERONIKA GARDA}

After explanation of concepts relating to subjective spatial perception the study presents the main issues influencing the mental picture. According to relating literature the author outlines the possibilities of use the mental map (as research method). Based on the size of examined spatial units the scopes of method are described in researches conducted on settlement, regional and national (continental) level. 